\title{
GROWTH AND SOME CARCASS CHARACTERISTICS- OF GROWING PIGS FED FULL-FAT SOYBEAN-BASED DIETS CONTAINING THREE PROTEIN SUPPLEMENTS
}

\author{
FANIMO A. O. \\ Department of Animal Production \& Health, University of Agriculture, Abeokuta, Nigeria. \\ Received 05 May 1995; Accepted 20 May 1996.
}

\begin{abstract}
Thirty-six Large White $X$ Landrace growing pigs were randomly allotted in a $3 \times 3$ factorial arrangement. The two dietary variables were protein source (Fish meal FM, Chicken offal meal-COM and full-fat soybean - FFSB) and processing time of FFSB (30, 60, 90 minutes). Pigs on 90 minutes processed FFSB performed slightly better than those on 60 and 30 minutes as regard growth rate and feed to gain ratio. The diets had no significicant effect on slaughtering performance. However, the general trend showed a numerical increase in estimated loin eye area, back fat and abdominal fat with increased processing time of FFSB. Chicken offal meal also slightly increased the backfat and abdominal fat.
\end{abstract}

Keywords: Carcass characteristics, growing pigs, full fat soy bean.

\section{INTRODUCTION}

Fish meal has remained the standard against which most other protein feedstuffs intended for inclusion in practical type diets have been compared because of its high content of lysine, methionine and cystine as well as its contribution of some unidentified growth factors. It has the added advantage of good flavour and taste which enhance palatability and acceptability of diets. In recent times, there has been a shortage of fish meal in the country and its cost has significantly increased relative to other protein concentrates. Because of this high cost, the use of substitute protein concentrates to reduce the cost per unit finished diets is necessary. Such substitutes include chicken offal meal and full-fat soybean.

Full-fat soybean has been shown to be valuable in reducing the conventional requirement of fish meal in monogastric animal feeds (Aumaitre, 1985, Fanimo and Tewe, 1994) while chicken offal meal, a processed edible parts from poultry processing plants has been found to be as effective as fish meal when used to supplement a simplified corn-soya ration (Fuller, 1956). The present study was, therefore, conducted to compare the growth and slaughtering performance in growing pigs fed these three protein concentrates in diets based on full-fat soybean processed at three time durations.

\section{MATERIALS AND METHODS}

\section{SOYBEAN}

Raw soybean packed in jute bags were lowered into boiling water in half drum and allowed to boil for 30 minutes, 60 minutes and 90 minutes, respectively. Timing of cooking commenced when the water reached the temperature of $100^{\circ} \mathrm{C}$ after introducing the bags. The boiled seeds were drained of water, sundried to less than $10 \%$ moisture level within 3 days in the dry month of January. This was then ground and bagged, ready for use.

\section{Chicken Offal Meal:}

Broiler chicken intestines (gut content inclusive) were obtained from the slaughter house of Zartech Agricultural Industries, Ibadan, Nigeria. The intestines from the day processing, collected between 1600 hours and 18.00 hours were cleaned of residues, and washed with water to remove dirt. These were then transferred into a half drum, where the "wet rendering" method of processing was applied. This entailed cooking the intestines at a temperature of about $150^{\circ} \mathrm{C}$ for 3 to 4 hours. The broth was left to cool, partially defatted by decanting the oil at the top layer and further pressed gently to expel more oil and water. The liquid in the residues was 
FANIMO, A. O.

TABLE 1: COMPOSITION OF EXPERIMENTAL DIETS FED GROWING PIGS (x)

\begin{tabular}{|c|c|c|c|c|c|c|c|c|c|}
\hline Diets & 1 & 2 & 3 & 4 & 5 & 6 & 7 & 8 & 9 \\
\hline Processing time (Min.) & 30 & 60 & 90 & 30 & 60 & 90 & 30 & 60 & 90 \\
\hline Maize & 45.0 & 45.0 & 45.0 & 44.54 & 44.54 & 44.54 & 42.50 & 42.50 & 4250 \\
\hline Maize Offal & 25.00 & 25.00 & 25.00 & 25.00 & 25.00 & 25.00 & 25.00 & 25.00 & 25.00 \\
\hline Fish meal & $2.5^{\circ}$ & 2.5 & 2.5 & - & - & $\cdot$ & $\cdot$ & $\cdot$ & - \\
\hline Chicken offal meal & - & - & - & 2.71 & 2.71 & 2.71 & - & - & - \\
\hline Full fat soybean & 25.0 & 25.0 & 25.0 & 25.0 & 25.0 & 25.0 & 30.0 & $\therefore 30.0$ & 30.0 \\
\hline Bone meal & 1.25 & 1.25 & 1.25 & 1.25 & 1.25 & 1.25 & 1.25 & 1.25 & 1.25 \\
\hline Oyster shell & 0.75 & 0.75 & 0.75 & 0.75 & 0.75 & 0.75 & 0.75 & $\cdot 0.75$ & 0.75 \\
\hline Premix ${ }^{*}$ & 0.25 & 0.25 & 0.25 & 0.25 & 0.25 & 0.25 & 0.25 & 0.25 & 0.25 \\
\hline Salt & 0.25 & 0.25 & 0.25 & 0.25 & 0.25 & 0.25 & 0.25 & 0.25 & 0.25 \\
\hline \multicolumn{10}{|c|}{ Determined Analysis (DM basis) } \\
\hline Crude protein & 18.8 & 17.1 & 18.9 & 18.9 & 17.7 & 16.1 & 16.1 & 18.0 & 18.4 \\
\hline Crude fibre & 5.2 & 4.6 & 3.9 & 4.3 & 5.4 & 5.3 & 5.5 & 4.0 & 4.9 \\
\hline Ether extract & 4.1 & 4.0 & 5.4 & 5.0 & 5.1 & 5.7 & 4.6 & 4.0 & 4.6 \\
\hline Calculated Analysis & & & & & & & & & " \\
\hline Methionine & 0.32 & 0.33 & 0.33 & 0.30 & 0.31 & 0.31 & 0.30 & 0.31 & 0.31 \\
\hline Lysine & 0.99 . & 1.01 & 1.03 & 0.94 & 0.96 & 0.98 & 0.99 & 1.02 & 1.04 \\
\hline Calcium & 0.40 & 0.38 & 0.36 & 0.29 & 0.27 & 0.25 & 0.31 & 0.28 & 0.26 \\
\hline Phosphorus & 0.42 & 0.42 & 0.42 & 0.36 & 0.36 & 0.36 & 0.34 & 0.34 & 0.34 \\
\hline
\end{tabular}

*Supplied the following per kg of ration: Vitamin A, II785 IU; Vitamin D, 1944.3 IU; riboflavin, 5.4mg; pantothenic acid, $9.82 \mathrm{mg}$; nicotinic acid, $24.55 \mathrm{mg}$; folic acid, $0.98 \mathrm{mg}$; choline chloride, $4.0 \times 10^{5} \mathrm{mg}$; Vitamin E, $4.91 \mathrm{IU}$; Vitamin $\mathrm{K}, 2.20 \mathrm{mg}$; Vitamin $120.01 \mathrm{mg}$; methionine, $245.53 \mathrm{mg}$; cobalt, $1.23 \mathrm{mg}$; iodine, $0.98 \mathrm{mg} ; \mathrm{Cu}, 9.82 ; \mathrm{Mn}, 55.0 \mathrm{mg} ; \mathrm{Zn}, 49.11 \mathrm{mg}$ and $\mathrm{Fe}$, $19.64 \mathrm{mg}$.

evaporated until the material became gluey. Two and half percent of the measured weight of the material was added as salt $(\mathrm{NaCl})$ and worked in immediately as preservative. The sample was sun-dried to less than $10 \%$ moisture level and ground, ready for use. The sun drying took about 3 days in the dry month of January. The fish meal was obtained from Pfizer Livestock Feed Plc., Lagos.

\section{Dietary Treatments}

Nine diets were formulated (Table 1) to be isocaloric and isoproteinous containing $18 \%$ crude protein and $2900 \mathrm{kcal} / \mathrm{kg} \mathrm{ME}$. There were three protein concentrates (fish meal, chicken offal meal and full-fat soybean) and three processing times for full- fat soybean ( 30 , 60,90 minutes).

\section{Experimental Design}

Thirty-six Large White $x$ Landrace crosses of pigs with an average initial live weight of $24.05 \pm 0.25 \mathrm{~kg}$ were randomly allotted to treatments on basis of weight and sex with two replicates per treatment. The pigs were housed in a concrete floored pen. The treatment were arranged such that there were three protein sources and three cooking duration for full-fat soybean in a $3 \times 3$ factorial.

\section{Management of Animals}

The two animals per pen were group-fed $a d$ libitum. Water was also provided at all times. Prior to commencement of study, the experimental animals were dewormed with piperazin. Pens were cleaned regularly and animals allowed an adjustment period of one week on their respective diets after which live weight of pigs on test diets were recorded weekly. The duration of the trial was 70 days. 


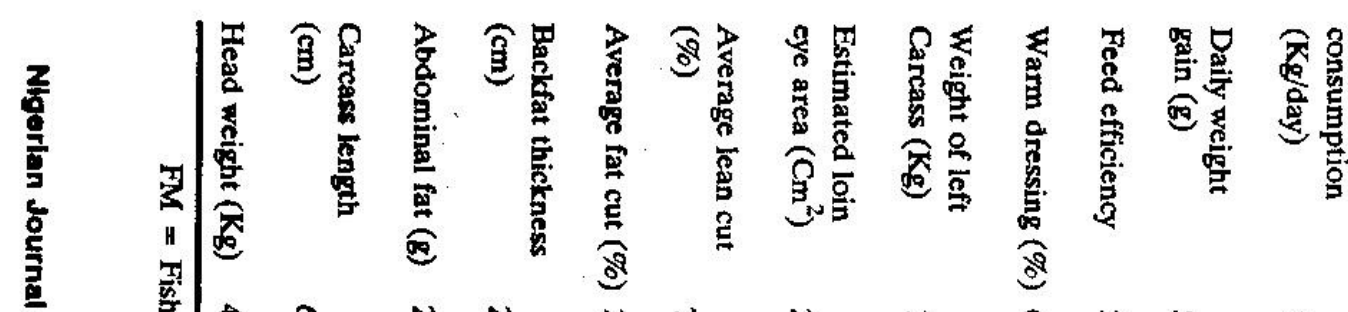

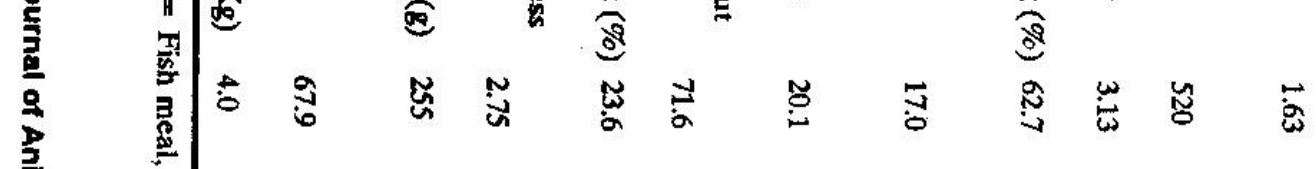

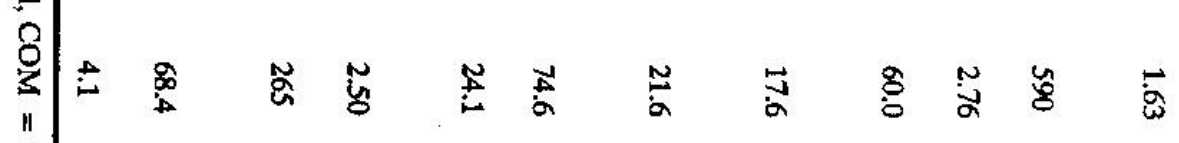

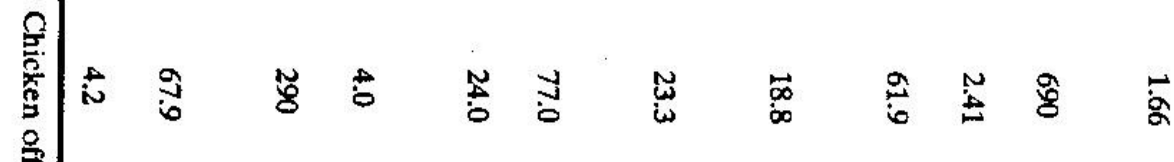

送

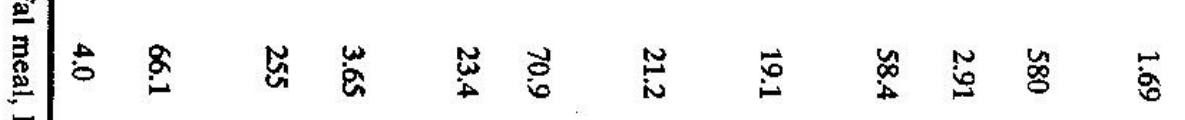

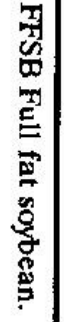

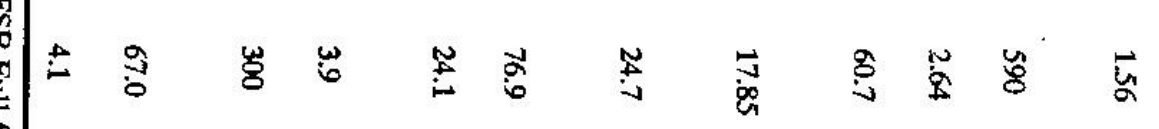

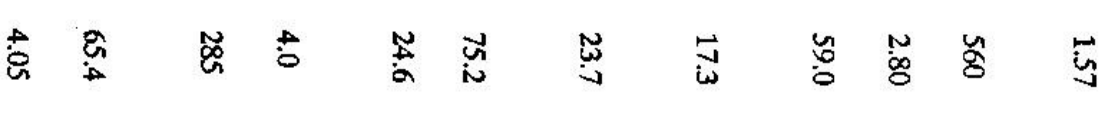

㟧

i.

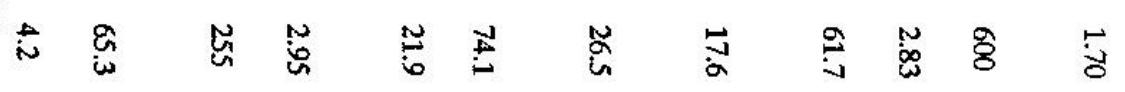

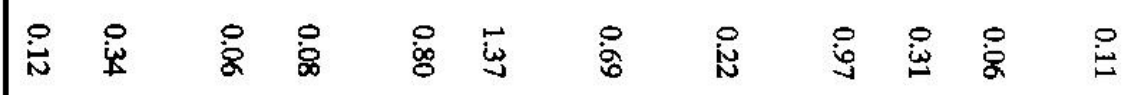

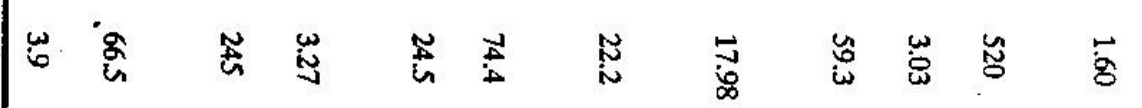

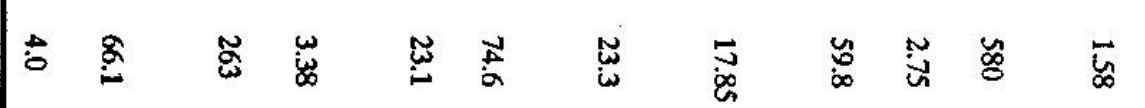

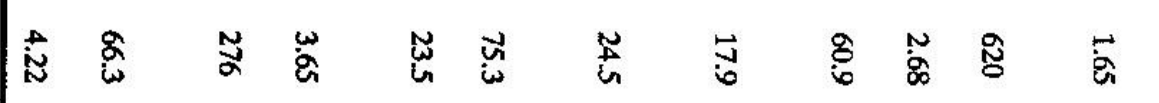

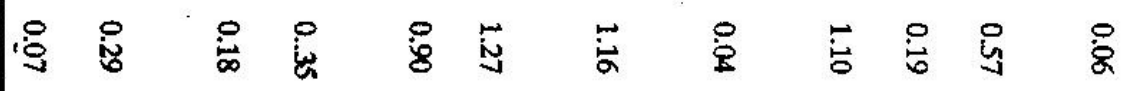

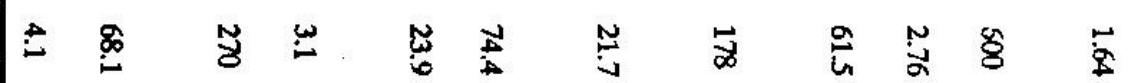

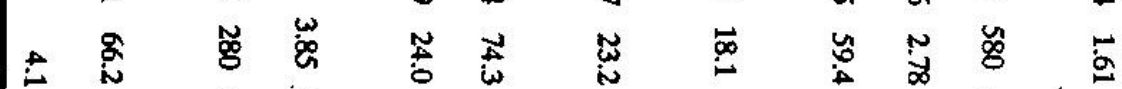

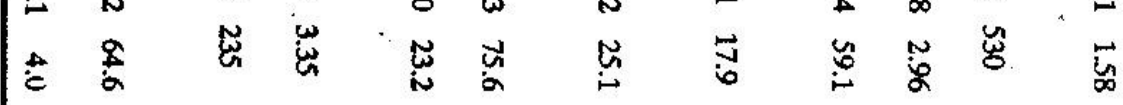

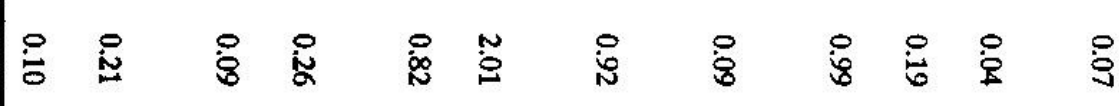

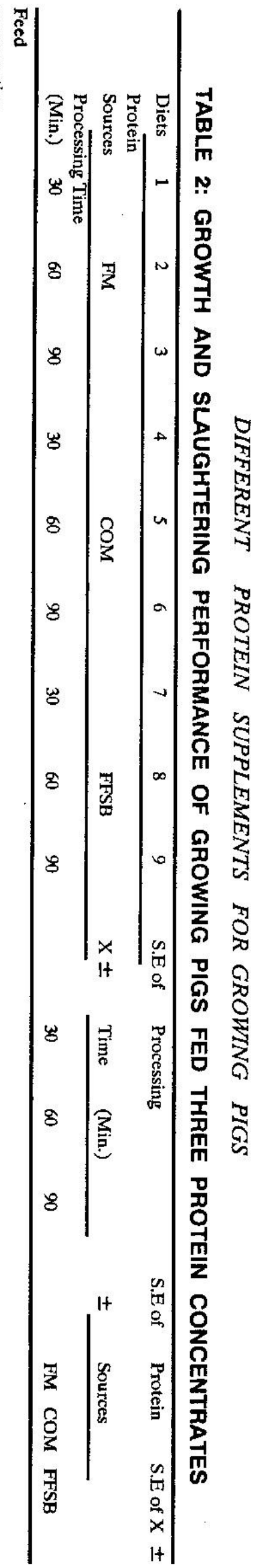




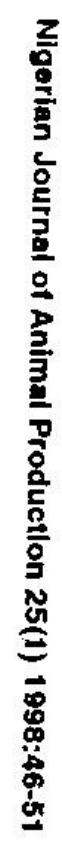

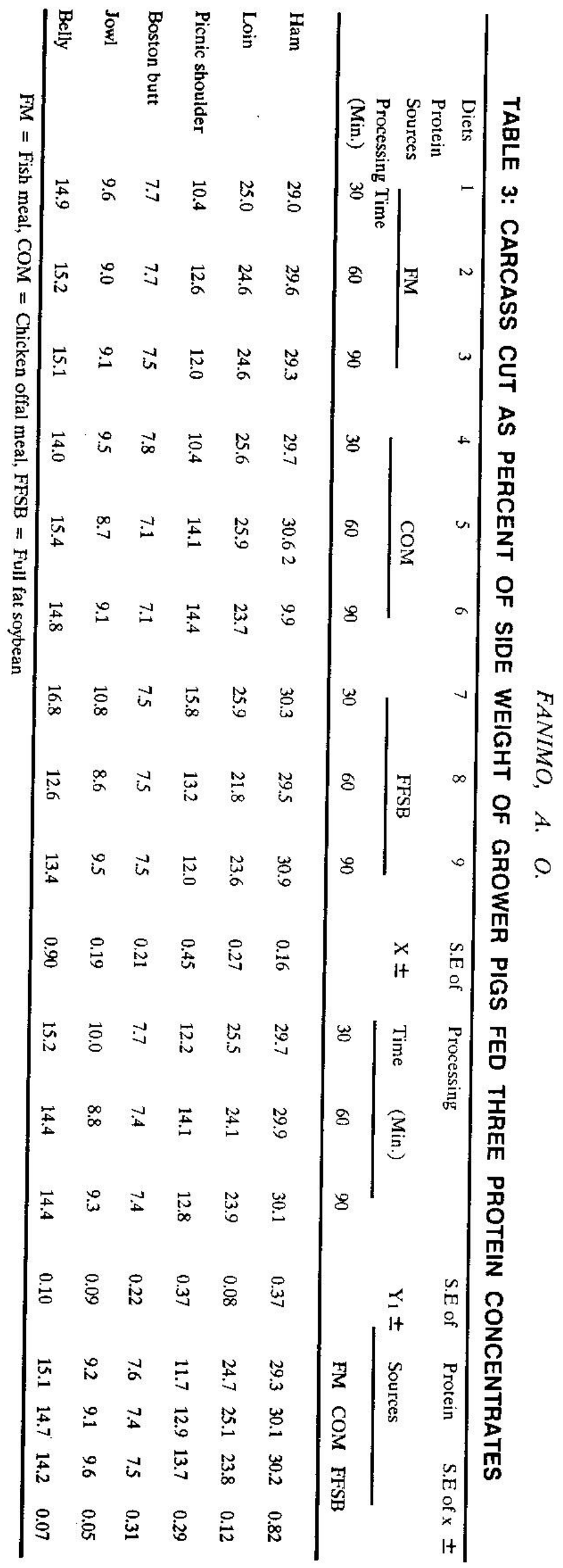




\section{DIFFERENT PROTEIN SUPPLEMENTS FOR GROWING PIGS}

\section{Carcass Studies}

As the animals attained the predetermined slaughter weight of $60 \pm 2.5 \mathrm{~kg}$, they were fasted for 18 hours during which only water was given. They were killed the following morning by stunning, bled with knife after which they were dressed for carcass grading using the methods of Buck (1963).

\section{Analytical Techniques}

Diets were analysed for their proximate constituents using the Methods of (A.O.A.C., 1990).

\section{Statistical Analysis}

Analysis of variance was carried out according to the method outlined by Steel and Torrie (1980).

\section{RESULTS}

As shown in Table 2, the growth performance criteria were not significantly influenced either by the different processing time of FFSB or by the protein sources, although weight gain increased slighily with increased cooking durations of FFSB with pigs fed 30 minutes cooked FFSB having $520 \mathrm{~g}$ while those fed 90 minutes cooked FFSB having $620 \mathrm{~g}$. The same trend was observed for feed to gain ratio with 90 minutes cooked FFSB having the best value of 2.83. Animals fed fish meal had somewhat better overall performance. Tables 2 and 3 summarize the results of the slaughtering performance in relation to the cooking duration of full-fat soybean and the protein sources fed. There were no significant differences $(P>0.05)$ between groups. Generally, back fat thickness and abdominal fat increased with the cooking duration of FFSB while on the other hand, chicken offal meal had the highest value for back fat thickness and abdominal fat among the three protein concentrates. Pig fed FM had slightly higher warm dressing percentage.

\section{DISCUSSION}

Generally, the performance of animals fed the 90 minutes processed FFSB was better than those fed with the 30 - and 60 - minutes processed FFSB although the difference was not significant. Consequently, neither the rather high residual activity of trypsin inhibitors of 30 minutes processed FFSB (about 4.43 Tiumg $^{-1}$ ) nor the indicated possibiitity of overheating for the 90 minutes processed FFSB had major negative effects on animals performance. It was however not possible to predict exactly the suitability of differently heated FFSB as feedstuff for pig from the results of chemical analysis of trypsin inhibitors alone. The variations observed in performance as influenced by processing time of FFSB was consistent with the observations of Veltmann et al (1987), that the nutritive value of a protein supplement can be improved by processing due to increased availability and digestibility of intrinsic nutrients.

Regarding protein sources, there were no significant differences between the three protein concentrates. These observed results are inconsistent with the earlier reports of Fetuga (1972) who reported lower performance for rats fed plant protein concentrate compared to those fed animal proteins. However, FFSE was used in this study contrary to groundmut cake used by Fetuga. Soybean is the most superior of all vegetable protein concentrates (Balloun, 1980). Results similar to those in this experiment were published by Fanimo and Tcwe (1994), who found similar performance of rats fed FFSB, FM, and COM.

In this experiment, slaughtering performance was not affected. There were no significant differences in linear carcass measurements and carcass cuts as percent of left side. The reason for this might be that the daily energy intake was equal for all groups and the dietary protein/energy ratio was higher than that recommended by the Gesellschaft fur Ernahrungsphysiologie (1987). These results are in contradiction to the work of Wahlstrom et al (1971), who reported a higher carcass percentage and of Seerly et al (1974), who found small eye muscle area together with more intramuscular fat in carcass after fecding FFSB. 
Generally, there did not appear to be any roticeable effect of treatment of FFSB on the arcass measurements reported. It is generally considered that qualitative aspects of carcass it are perhaps more important guides to the use of full-fat soybeans in pig dicts, as it has heen appreciated that high dietary levels of any raw materials containing appreciable lcvels of polyunsaturated fatty acid will lead to similar levels in carcass fat (Monari, 1988). This may be associated with softer and poorer keeping quality, against which consumers might discriminate.

\section{REFERENCES}

\section{ASSOCIATION OF OFFICIAL}

ANALYTICAL CHEMISTS (A.O.A.C.) (1990). Official Methods of Analysis: 15th ed., Washington D.C.

AUMAITRE, A. (1985). L'utilizationdela graine de soja extrude dans l'alimentation du percolate sevre precocement. In "Proceedings of Onidolcis Symposium"' 111 Congress sur le soja, Paris, France.

BALLOUN, S.L.(1980) Soybean mcal in poultry nutrition. Amcrican Soybean Association Publication. St. Louis Missouri, USA.

BUCK, S. P. (1963). A comparison of pigs slaughtered at three different weights. I. Carcass quality and performance J. Agric Sci. 60: 19 - 24.

FANIMO, A. O. and TEWE, O.O. (1994). Comparatative nutritional evaluation of full-fat soybean and some animal protein concentrates. Trop. Oilseed Joumal. 2(1).

FETUGA, B.L. (1972). Assessment of the protein quality of certain Nigerian foods and fecdstuffs in the nutrition of pig and rat; $P$ h.D Thesis, Department of Animal Science, University of lbadan.

FULLER, H.L. (1956). The value of poultry by-products as sources of protein and unidentified growth factors in broiler rations.

Poult. Sci. 35:1143.

GESELLSCHAFT FUR

ERNAHRUNGSPHYSIOLOGIE (1987).

Empfehlungen zur Energy-und Nahrstoffversorgung der Schweine. DLG, Frank furt/Main, Germany, pp. 35 - 40 .

MONARI, S.E. (1988). Fullfat soya Handbook. American Soybearr Association Publication, Brussels, Belgium, Pp. 21 - 26.

SEERLEY, R.W. EMBERSON J.W. MCCAMPBELL, H.C., BURDICK, D. and GRIMES I.W (1974). Cooked Soybeans in swine and rat diets. J. Anim. Sci. 39: 1082 1091.

STEEL, R.G.D and TORRIE, J.H. (1980) Principles and procedures of Statistics. McGraw-Hill. New York.

VELTMANN, J.K. Jr., HAHSEN, B.C. TANKSLEY, T.D., KNABE, D. and LINTON, S.S. (1987). Comparison of nutritive value of different heat treated commercial soybean meals: Utilization by chicks in practical type rations. Poult. Sci. 65 : $1561-1570$.

WAHLSTROM, R.C. LIBAL, G.E. and BERNS, K.J. (1971). Effect of cooked soybeans on performance, fatty acid composition and pork carcass characteristics. J. Anim. Sci. 32: 891 - 894. 